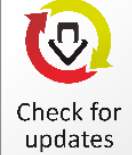

updates

Article Type: Research Paper

\title{
Mental Accounting Experiment: Mode of Payment Effect on Treating Money
}

\author{
Etik Kresnawati ${ }^{1,2 *}$, Ahmad Bunyan Wahib ${ }^{3}$, and Ruspita Rani Pertiwi ${ }^{1}$
}

\section{DPEN}

\author{
AFFILIATION: \\ ${ }^{1}$ Department of Islamic \\ Accounting, State Islamic \\ University Sunan Kalijaga, \\ Yogyakarta, Indonesia. \\ ${ }^{2}$ Department of Accounting, \\ Universitas Muhammadiyah \\ Yogyakarta, Yogyakarta, Indonesia. \\ ${ }^{3}$ Department of Islamic Family \\ Law, State Islamic University Sunan \\ Kalijaga, Yogyakarta, Indonesia.
}

*CORRESPONDENCE:

e_kresna@yahoo.com

THIS ARTICLE IS AVALILABLE IN:

http://journal.umy.ac.id/index.php/ai

DOI: 10.18196/jai.2003133

\section{CITATION:}

Kresnawati, E., Wahib, A. B., \& Pertiwi, R. R. (2019). Mental Accounting Experiment: Mode of Payment Effect on Treating Money. Journal of Accounting and Investment, 20(3), 339-353.

\section{ARTICLE HISTORY}

Received:

18 June 2019

Reviewed:

4 August 2019

Revised:

17 August 2019

Accepted:

29 August 2019

\begin{abstract}
This study examines the argument of mental accounting theory that individuals will behave differently in treating money. More specifically, this study empirically tests whether the difference in payment mode, cash and debit cards, will affect the amount of money spent by individuals when shopping and donation. The data were collected through a laboratory experimental design involving 76 female students from Muhammadiyah Boarding School and Pondok Pesantren Baitussalam Yogyakarta. Using MANOVA as the analysis tool, the results showed that the mode of payment did not affect the amount of money for shopping, but it affected the amount of donation. Subjects who used a debit card show an average number of donations that were larger compared to the subjects in the cash group. The results implied that debit card users, especially students, in this case, are not proven to behave more consumptively as predicted by the theory. While the positive impact is that debit cards can be a means for students to do more charity through donations. Thus, these results are in line with the objective of a cashless society program launched by Bank Indonesia. The important thing that should not be ignored in Less Cash Society programs at educational institutions is the policy of limiting the amount of money students can spend.
\end{abstract}

Keywords: Mental Accounting; Mode Of Payment; Shopping; Donation.

\section{Introduction}

On August 19, 2014, Bank Indonesia (BI) enacted National Non-Cash Movement (NNCM/Gerakan Nasional Non). There are several reasons for this movement, such as to improve safety, convenience, efficiency, transparency and accountability of economics transaction. This enactment is a follow up from the review of bank Indonesia Initiative Team related to Grand Design of Effort to Increase the use of Non-cash Payment (Bank Indonesia, 2006). Four years from enactment, until the end of 2018, there was a significant growth in the volume and value of transactions using card based payment instruments (CBPI). In Table 1, we present data on increasing transaction value for both credit cards and ATM and Debit Cards (Bank Indonesia, 2019). It shows a shift in people's preferences when choosing payment instruments in their financial transactions. The data also indicates a positive public response to Bank Indonesia's efforts to realize less cash societies 
Kresnawati, Wahib, \& Pertiwi

Mental Accounting Experiment: Mode of Payment Effect on Treating Money

Table 1 Circulation Volume and Value of CBPI Transactions

\begin{tabular}{ccccc}
\hline Year & \multicolumn{2}{c}{ Number of Outstanding CBPI (Unit) } & Transaction Value (in Millions of Rupiah) \\
& Credit Card & ATM + Debit Card & Credit Card & ATM + Debit Card \\
\hline 2012 & 14.817 .168 & 77.752 .552 & 201.840 .736 & 3.065 .080 .042 \\
2013 & 15.091 .684 & 89.462 .289 & 223.369 .577 & 3.797 .370 .438 \\
2014 & 16.043 .347 & 105.828 .204 & 255.057 .458 & 4.445 .073 .437 \\
2015 & 16.863 .842 & 120.279 .206 & 280.543 .930 & 4.897 .794 .435 \\
2016 & 17.406 .327 & 136.148 .350 & 281.020 .518 & 5.623 .912 .646 \\
2017 & 17.244 .127 & 164.478 .449 & 297.761 .229 & 6.200 .437 .636 \\
\hline 2018 & 17.275 .128 & 161.329 .105 & 314.294 .067 & 6.927 .267 .513 \\
\hline
\end{tabular}

Source: Bank Indonesia, 2019

To accelerate this program, Bank Indonesia cooperated with state bank partners, including BRI, BNI and Mandiri, launched non-cash areas in several universities and Islamic boarding schools. It is expected that this effort will become a pilot in the context of realizing less cash society (LCS). One example of the LCS program is the inauguration of the Sunan Pandanaran Islamic Boarding School (PP), as the first boarding school to become a non-cash area, by the BI Yogyakarta Regional Office on November 16, 2015. With around 3,000 students and supported by 14 business units owned, this boarding school is expected to be the pilot for other boarding schools in Indonesia. Using a Brizzi card, issued by BRI, all students of PP Sunan Pandanaran are required to conduct economic transactions electronically in 14 business units in the boarding school environment (Republika Online, 2015).

Theoretically, mental accounting explains how someone makes decision on money transactions (Thaler, 1980, 1985, 1999). According to this theory, someone will code, categorize and budget inflow and outflow monetary resources and how the process takes place to gain profit. Coding and categorization of inflows and outflows of the money is carried out by individuals in a way that violates the property of equivalence (functionality), in which the money received can be used to buy anything, and that the origin of the money received should also not affect how the money is spent (Shefrin \& Thaler, 1992). In this case different payment method is suspected able to affect someone in spending his money.

Previous studies (Prelec \& Loewenstein, 1998; Prelec \& Simester, 2001; Soman, 2003, Raghubir \& Srivastava, 2008; and Thomas, Desai, \& Seenivasan, 2011) indicated that payment method affected perception on the amount of money being paid. Compared to cash, consumers who went shopping using credit cards would experience "losing" or "pain" less on the expenses that have spent (Soman, 2001). It also works similarly to their sensitivity towards price (Monger \& Feinberg, 1997). Therefore, it encourages consumers to possibly spend more money when paying using the credit card than cash.

In practice, the individual consumer is often offered by shop/supermarket cashiers to donate the change of his shopping which is rounded to certain digit, for instance, the donation program runs by retailer network Alfamart, Alfamidi, Indomaret, and Matahari. 


\section{Kresnawati, Wahib, \& Pertiwi \\ Mental Accounting Experiment: Mode of Payment Effect on Treating Money}

Generally, the amount of money rounded that is offered by the cashier is not too big (to the nearest 500 IDR). This way persuades the consumers to consent the donation offers. Therefore, payment method does not only influence individual consumers' shopping behaviour of but also their willingness to donate. Islamic boarding school as an education and religion institution is expected as social donation collector by giving direction to its students to increase alms, one of them is by rounding the shopping when they shop in the boarding school cooperative.

Using mental accounting as its grand theory, this study aims to examine the effect of GNNT enactment in Islamic boarding schools towards consumption and donation behaviour of its students. This theory contends that individuals classify funds differently and therefore are susceptive to irrational decision-making in their spending and investment behavior. It is different from the previous studies which focused on consumers consumption pattern comparison by paying attention to payment physical form, using credit card and cash (Hirschman, 1979; Prelec \& Simester, 2001; Raghubir \& Srivastava, 2008; Thomas et al., 2011), this research focuses on the comparison between debit card and cash. This study also adds consumer behaviour in donating as an activity carried out simultaneously with shopping activity.

In general, this study aims to confirm the prediction of mental accounting theory that forms of payment can affect individual decisions when shopping. This theory is commonly used to explain consumer personal budgeting in managing self-control issues (Galperti, 2019). Using Islamic boarding school students in Yogyakarta as the sample, the questions that will be answered in this study are: 1) Does shopping payment using a debit card encourage students' consumptive behaviour higher than when paying by cash; 2) Does shopping payment with a debit card encourages students to donate more than by cash. Data were collected by experiment using minimarket shopping software that was designed according to the needs of this study.

This study is interesting and important to conduct because: (1) from a theoretical point of view, studies conducted by Soman (2001) and Leon (2012) showed that debit card is a unique form of payment so that it needs to be explored further. A debit card has properties between credit cards and cash, so it is less precise compared to credit cards. Debit cards have the same payment form (physical form) as credit cards but not for payment couplings (shopping satisfaction and the pain of losing money paying at the same time). On the other hand, debit card differs from cash in terms of payment forms, but it has similarities in payment couplings. Some studies often classify debit cards into credit cards by referring to its physical form, but they ignore that people will lose the same amount of money by cash payments at once (for example: Morewedge, Gilbert, Berkovits, \& Wilson, 2007). For this reason, the author suspects that the consumptive effect on a debit card may not be as large as a credit card; (2) From a practical perspective, the decision of Bank Indonesia to cooperate with Islamic boarding schools (educational institutions) as a model for the NNCM program should be reviewed through empirical research. It is expected that the results of this study can give contribution to Bank Indonesia, supporting banks and educational institutions to create a NNCM design that is appropriate to the environment of the educational institution, so 


\author{
Kresnawati, Wahib, \& Pertiwi \\ Mental Accounting Experiment: Mode of Payment Effect on Treating Money
}

that concerns related to the use of debit cards as a means of spending for the students, that theoretically will encourage consumptive behaviour, can be avoided or minimized.

\title{
Literature Review and Hypotheses Development
}

\section{Non-Cash Transactions in the Islamic View}

Money is an important payment method in selling and buying activities (Rosiana, 2018) divided the money function into two, which is as a unit of calculation (qiwam ad-dunya) and as a medium of exchange used to obtain other goods (al-mu'awidhah). In the time of the Prophet Muhammad, the buying and selling system used dinars (gold and silver) and copper as a medium of exchange. Currently, the development of the payment model has experienced significant changes. To meet the need for faster, safer and more efficient transactions, non-cash financial instruments have emerged (namely: credit cards, debit cards) and electronic money such as Tcash, OVO, GoPay, Flash, and Brizzi.

One important element in maqashid sharia ${ }^{1}$ is maintaining or safeguarding assets, in which there is an element of benefit in wealth (Muamar \& Alparisi, 2017). Based on this concept, non-cash financial transaction instrument (debit card) is in accordance with sharia principles, including 1) It does not contain al-fadl usury (i.e.: charging of 'interest' through the exchange of the same commodity, but of a different quality or quantity) because, at the time of exchange, the amount of cash deposited to the card manager has the same value as the amount listed on the debit card; 2) It does not contain annasih usury (i.e.: additional which is given from someone who gave the debt as the compensation of payment postponement) because when there is a shopping transaction, there is no payment suspension from the debit card issuer to the merchant; and (3) There is a clear contract between the customer and the debit card issuer as well as with the trader.

The development of methods in muamalah should be addressed openly by sticking to sharia principles. Likewise, the development of payment methods. When it eases the users and does not conflict with Islamic law, then Muslims will be moved to use it.

\section{Payment Model and Shopping Behaviour}

Individual decisions in spending money should be independent of how the transaction is conducted/paid. It necessary that individual should only consider the balance between the amount of money spent and the benefits obtained from the goods purchased. However, the mental accounting literature suggests that the individual codes and

\footnotetext{
${ }^{1}$ Maqashid sharia is an ultimate goal of Islamic law which promoting welfare and benefit values also eliminate misery. According to Al-Ghazali (1991, as quote by Antonio et al., 2012), it consists of 5 things, namely: guarding religion, soul, mind, family and wealth. Anything that guarantees the preservation of those five essential is called welfare/benefit (maslahah) and every matter that escape from it called damage (mafsadah).
} 


\section{Kresnawati, Wahib, \& Pertiwi \\ Mental Accounting Experiment: Mode of Payment Effect on Treating Money}

categorizes the inflow and outflow of money in a way that violates the principle of equivalence.

However, the mental accounting literature suggests that the individual codes and categorizes the inflow and outflow of money in a way that violates the principle of comparability. The results showed the results that support the prediction of mental accounting that individual behaviour in spending money proved to be influenced by the payment model (for example: Hirschman, 1979; Prelec \& Simester, 2001; Raghubir \& Srivastava, 2008; Thomas et al., 2011; Helion \& Gilovich, 2014). In general, the payment model is divided into two different attributes, they are payment coupling and payment form. Payment coupling refers to a combination of satisfaction with the product purchased and the pain of spending some money to get the product (Thaler, 1980). While the payment form refers to the different forms / physical ways of payment but it holds the same monetary value (Raghubir \& Srivastava, 2008).

Research generally classifies these payment methods into two, which are by using a card (generally a credit card) and by issuing cash. Credit and cash cards come in different forms and couplings. Cash payment is the most "transparent" payment in terms of physical and monetary amounts so that it is easier for individuals to remember how much money was spent on certain products. This transparency will make individuals very concerned about the real amount of money that will be spent (Raghubir \& Srivastava, 2008). While payment by credit card is less transparent because it does not involve physical price repetition so that it will reduce the "pain of paying" (Soman, 2001). This will encourage the individual to shop more compared to when paying cash. Soman (2001) also reported that consumers who use credit cards might underestimate the amount of money they spend so there is a tendency for overspending.

The results of previous studies supported overspending predictions on individuals who shop using credit cards. Hirschman (1979) used actual transaction data to test an individual's shopping behaviour. The results showed that consumers who used credit cards spent more money to shop than consumers who used payment instruments in the forms of cash or checks. Soman (2001) explained that consumers who pay using a credit card, are more likely to obey their own will and buy items that are not needed and are not planned to be bought before. Prelec and Simester (2001) conducted an auction in which participants bid for sports competition tickets that would be purchased by the winner of the auction the next day using cash or credit cards. Participants were randomly assigned to two forms of payment. The test results showed that the willingness to pay was greater in payment conditions using a card instead of cash.

Experimental tests on credit cards were also conducted by Raghubir and Srivastava (2008) and Thomas et al. (2011). Raghubir and Srivastava (2008) asked the experiment participants to estimate how expensive food was at a restaurant. The results showed that participants who paid using credit cards estimated prices higher than those who paid with cash. While Thomas et al. (2011) conducted an experiment on consumers' impulsive responses to unhealthy foods. Similar to the previous studies, the results of 


\section{Kresnawati, Wahib, \& Pertiwi \\ Mental Accounting Experiment: Mode of Payment Effect on Treating Money}

the study showed that consumers were more likely to buy unhealthy food products when paying using a credit card than when they paid cash.

In contrast to credit cards that get a lot of attention from researchers, the researcher only found a little research in this field regarding to debit cards (for example: Leon, 2012; Runnemark, Hedman, \& Xiao, 2015). A debit card is a type of payment that has the characteristics of a credit card and cash (Leon, 2012). Based on its physical form, a debit card has the same properties as a credit card, that is in terms of physical transparency. While in terms of coupling, the debit card has the same nature as cash payments, in which there is no time lag between the consumption of goods with the pain of losing money. Therefore, compared to a credit card, a debit card has the same level of physical transparency but it is different from the credit card when compared to cash payments, debit card will reduce the feeling of "paying" because consumers do not directly see the amount of cash issued (Raghubir \& Srivastava, 2008).

Transparency of payment methods and the pain of separating from money are keywords in explaining consumption behaviour with a debit card. Transparency of payment methods is the appearance (salience) when "parting" with money (Soman, 2003). The more transparent the payment method (the more the payer feels the outflow of money), the more it feels the pain of paying (Prelec \& Loewenstein, 1998). The level of transparency can be by source or method of payment and temporal separation between consumption and payments made.

Previous research conducted by Leon (2012) with the experimental design of 152 participants could not prove that there were differences in participants who used credit cards, debit cards, cash, gift cards (vouchers) and the control group in estimating dinner prices. It is possible that there were no differences between groups due to the experimental design which did not include the card logo. While the research results by Runnemark et al. (2015) with the assignment of product offerings to participants showed that willingness to pay in the group of participants who paid using a debit card was higher than participants in the cash group. The test results remained robust after being controlled by cash-on-hand restrictions, types of expenditure, price familiarity and consumption habits of the product being offered.

From the previous elaboration, it can be explained that the use of a debit card will impact an individual's tendency to overspending as well as a credit card. On the other hand, payment using a debit card will immediately reduce the amount of money in the individual account so that it resembles expenses in cash. Because the debit card has a nature between credit cards and cash, the researcher suspects that payments using a debit card will keep encouraging consumers to shop more compared to if the payment is cash. Based on these arguments it is hypothesized as follows:

$\boldsymbol{H}_{1}$ : Individuals will spend more money when shopping using a debit card than using cash. 


\author{
Kresnawati, Wahib, \& Pertiwi \\ Mental Accounting Experiment: Mode of Payment Effect on Treating Money
}

\title{
Payment Model and Donation Behaviour
}

As one of the pillars in the Indonesian Islamic financial system. The National Amil Zakat Agency Study Centre predicts that Indonesia's zakat potential in 2018 would reach Rp 217 trillion, but only 8 trillion was collected. That figure is $3.5 \%$ of the potential predicted and dominated by individual zakat compared to corporations (BAZNAS, 2019). Therefore, it is necessary to optimize the collection of donations from the community, not only for zakat. One way is by taking advantage of the convenience payment through online media, which is debit cards with a mobile banking application.

Still based on mental accounting theory which implies that individuals code and categorize the inflow and outflow of money in a way that violates the principle of equivalence, donors may behave as predicted by the theory. The research results by Soetevent (2011) confirmed that prediction. Individuals on the credit card group showed higher amount of donation compared to cash group.

When a donation service is attached to a shopping activity, individual shopping using a debit card will be more relevant to donating returns or rounding spending than the cash payment method. Individuals also do not need to bother spending a special amount of money to donate. Based on the following argument, the following hypothesis is proposed:

$\boldsymbol{H}_{2}:$ Individuals will donate more when shopping using a debit card than when using cash.

\section{Research Method}

\section{Data Collection}

This study used laboratory experiments to obtain data. The advantage of laboratory design is that researcher can have more control over variables that have the potential to influence the dependent variable (Nahartyo, 2012). Experimental participants were 90 female students of junior and senior high schools from Muhammadiyah Boarding School and Modern Baitussalam Islamic Boarding School. Both are in the Prambanan area, D.I. Yogyakarta. This study only used female students since according to the research results conducted by Mesch, Brown, Moore, and Hayat (2011), females influence the donating behaviour either in terms of amount or motivation which better compared to males.

Experimental participants were not exchanged because it is planned in both places to manage their financial transactions without cash in cooperation with Bank Indonesia and designated commercial banks. Therefore, participants were expected to represent the real conditions in the school environment. The author expected that this would reduce the weaknesses in the design of laboratory experiments, in which external validity is relatively weaker than field experiments. 


\author{
Kresnawati, Wahib, \& Pertiwi \\ Mental Accounting Experiment: Mode of Payment Effect on Treating Money
}

\title{
Research Variables
}

The experimental design used is between-subject. The independent variable is the shopping method, which is manipulated by spending using cash and debit cards. The dependent variable is the amount of expenditure and the amount of donations, measured by the amount of rupiah spent for both purposes.

\section{Experimental Treatment}

There were 2 computer rooms that were used, each consisted of 25 computers and each room was guided by two experimenter assistants. The first and second sessions consisted of 45 participants respectively. There were two stages in each session, namely the introduction of shopping simulation software and actual shopping practices. At the introduction of the software, participants were asked to conduct shopping transactions guided by the assistants. After they understood how to operate the software, then they continued to the actual implementation stage of the experiment.

Before entering the experiment-room, participants signed an attendance list and picked up a coupon containing a random computer table number. In group A, participants occupied the desks in which each desk has been provided with an envelope containing a member card of Amanah Supermarket and an envelope containing physical toy money resembling the original one with a nominal value of 1,000 IDR, 2,000 IDR, 5,000 IDR, 10,000 IDR, 20,000 IDR, 50,000 IDR, and 100,000 IDR that in total worth of 500,000 IDR. This amount of money was based on a preliminary survey that in average the students received an allowance of 400,000 IDR per month from their parents. The allocation of money with various nominal was to ease the participants to pay for shopping with the closest amount of rupiah. Whereas in group B, each participant received an envelope containing a debit card and a member card of Amanah Supermarket.

The next session, which was the actual experiment, was also held for 30 minutes. Due to time constraints, participants were only given the opportunity to make 4 times of shopping transactions at the maximum in August. Each participant had the right to choose to donate / or not to donate the rounding difference from the total expenditure to the nominal value of 1,000 IDR. For the participants who chose to donate, what they needed to do was choose the plus sign next to the donation column that automatically contains the difference of rounded expenses. Participants were also permitted to replace the amount of donations to a larger nominal. Whereas for participants who were not willing to donate the difference of their expenses would get the return of the rounded of shopping in the form of candies.

After completing the shopping simulation, the participants were asked to fill out a questionnaire that had been provided on each table. The questionnaire contained check-questions on manipulation, demographic, and questions related to participants' perceptions and preferences regarding spending and donations using cash and debit cards. Manipulation checks are used to ensure that participants understand how to operate the software according to their respective sections. While questions related to 
participants' perceptions and preferences related to spending and donations using cash and debit cards were obtained using a questionnaire used by Leon (2012) by changing the payment method from credit card to debit card in accordance with the purpose of this study.

Referring to Douglas and Craig (2007), in cross-country research, effective translation of questionnaires and survey instruments is important to note. Therefore, the researcher conducted a back-translation to ensure the equivalence of the language meaning and ensure a clear understanding of the questionnaire by respondents. According to Ding and $\mathrm{Ng}$ (2007), back-translation is conducted as follows:

1. Bilingual individuals translate instruments from the source language to the target language.

2. The second bilingual individual who does not know the words in the initial source language document translates the target language text back to the source language.

3. Comparing the initial source language version and the target language script that has been translated back to the source language (back-translation).

4. If there are important differences in the two language source documents, another target-language text is prepared which contains modifications to reduce this difference.

\section{Data Analysis}

Hypotheses 1 and 2 in this study were tested using the MANOVA statistical test technique. It is because what were tested consisted of independent variables, which were how to spend, which is categorical ( 0 for cash and 1 for debit cards), and 2 dependent variables, namely the amount of spending and the amount of donations. Hypotheses 1 and 2 are supported if the method of spending (cash and debit card) is significant at $\alpha \leq 5 \%$ on the test results of the between-sample effect.

\section{Result and Discussion}

\section{Demographic Data}

Table 2 shows respondent demographic data. The total number of students enrolled in the experiment was 90 people. From that total number, 8 people were excluded from the analysis because they did not fill out the entire questionnaire, 2 people did not pass the manipulation check, and 4 people did not consistently answer preference questions. Therefore, the data that can be used were 76 samples. 
Table 2 Respondent Demographic Data

\begin{tabular}{llccc}
\hline \multicolumn{1}{c}{ Categories } & Frequency & Percentage & $\begin{array}{c}\text { Cumulative } \\
\text { percentage }\end{array}$ \\
\hline Age & $<15$ yeras old & 56 & 73.7 & 73.7 \\
& 15-24 years old & 20 & 26.3 & 100.0 \\
School & Junior high school & 54 & 71.1 & 71.1 \\
& High school & 22 & 28.9 & 100.0 \\
Pocket & $<500,000$ IDR & 48 & 63.2 & 63.2 \\
money & 500,000 IDR $-1,000,000$ IDR & 26 & 34.2 & 97.4 \\
& $1,000,000$ IDR - 2,000,000 IDR & 2 & 2.6 & 100.0 \\
& Total & 76 & 100.0 & \\
\hline
\end{tabular}

It can be seen from the table above that $71.1 \%$ of the participants were junior high school students, while only $28.9 \%$ were in high school (22 out of 76 students). Strengthening the results of a survey conducted before the experiment, the students' allowance was dominated by the amount of approximately 500,000 IDR (63.2\% of the students), while $34.2 \%$ of the students got an allowance between $500,000-1,000,000$ IDR and only 2 students who got an allowance above 1,000,000 IDR.

\section{Result of Hypothesis Test}

Mental accounting literature suggests that individuals code and categorize the inflow and outflow of money in a way that violates the principle of equivalence. The results of this study supported the prediction of mental accounting that individual behaviour in spending money proved to be influenced by the payment model (for example: Hirschman, 1979; Prelec \& Simester, 2001; Raghubir \& Srivastava, 2008; Helion \& Gilovich, 2014). Hypothesis 1 that was be tested in this study is that individuals who shopped with a debit card would spend more money than individuals who use cash. As with the expenditure of donations tested in hypothesis 2 .

Before the MANOVA test was performed, the data normality test was conducted first. The results showed that the data distribution in this study was not normally distributed. Using the central limit theorem principle, the researcher ignored these results. The next test was the variance-covariance matrix dependency. The Box's $M$ test value was 139,239 with an $F$ value of 45,054 and a significance level of 0,000 . This showed that the variance-covariance matrix of the dependent variable was different. However, these results were still robust because the number of samples used for each cell was the same. The next was a multivariate test to test whether each factor of the independent variable influenced the group of dependent variables. The results showed a significant level of 0.071 which means there was a weak relationship between the way of shopping with the amount money spent and donations. Finally, the variance homogeneity test for all groups. The Levene's test showed a significant value for Total Expenditures of 0.511; while the amount of donation was 0.001 . This means that the amount of expenditure had the same variance, but not the amount of donations. The results of testing hypotheses 1 and 2 are presented in Table 3. 


\section{Kresnawati, Wahib, \& Pertiwi \\ Mental Accounting Experiment: Mode of Payment Effect on Treating Money}

The Test of Between-Subject Effect showed the effect of the shopping method on the amount of money spent on shopping and donations. Based on Table 3, it showed that the significance value for Total Spending was 0.343. This suggests that the method of payment using either cash or debit cards did not give a different effect on the amount of money spent by students. Thus hypothesis 1 in this study was not supported. While the significance value for Total Donations was 0.05 , which means that the payment method using cash and debit cards gave a different effect on the amount of spending done by students. The students tended to make more donations when shopping with a debit card compared to cash. Thus hypothesis 2 in this study was supported.

Table 3 Test of Between-Subject Effect

\begin{tabular}{|c|c|c|c|c|c|c|}
\hline Source & $\begin{array}{l}\text { Dependent } \\
\text { Variable }\end{array}$ & $\begin{array}{l}\text { Type III Sum of } \\
\text { Squares }\end{array}$ & df & Mean Square & $\mathbf{F}$ & Sig. \\
\hline \multirow{4}{*}{$\begin{array}{l}\text { Corrected } \\
\text { Model } \\
\text { Intercept }\end{array}$} & \multirow{2}{*}{$\begin{array}{l}\text { Total Shopping } \\
\text { Total Donation }\end{array}$} & $5632128342.118^{a}$ & 1 & 5632128342.118 & .910 & .343 \\
\hline & & $62737376.329^{b}$ & 1 & 62737376.329 & 3.955 & .050 \\
\hline & \multirow{2}{*}{$\begin{array}{l}\text { Total Shopping } \\
\text { Total Donation }\end{array}$} & 823441625581.592 & 1 & 823441625581.592 & 133.058 & .000 \\
\hline & & 124828352.645 & 1 & 124828352.645 & 7.869 & .006 \\
\hline \multirow{2}{*}{$\begin{array}{l}\text { Shopping } \\
\text { mode }\end{array}$} & \multirow{2}{*}{$\begin{array}{l}\text { Total Shopping } \\
\text { Total Donation }\end{array}$} & 5632128342.118 & 1 & 5632128342.118 & .910 & .343 \\
\hline & & 62737376.329 & 1 & 62737376.329 & 3.955 & .050 \\
\hline \multirow[t]{2}{*}{ Error } & \multirow{2}{*}{$\begin{array}{l}\text { Total Shopping } \\
\text { Total Donation }\end{array}$} & 457956106827.290 & 74 & 6188596038.207 & & \\
\hline & & 1173924822.026 & 74 & 15863848.946 & & \\
\hline \multirow[t]{2}{*}{ Total } & \multirow{2}{*}{$\begin{array}{l}\text { Total Shopping } \\
\text { Total Donation }\end{array}$} & 1287029860751.000 & 76 & & & \\
\hline & & 1361490551.000 & 76 & & & \\
\hline \multirow{2}{*}{$\begin{array}{l}\text { Corrected } \\
\text { Total }\end{array}$} & \multirow{2}{*}{$\begin{array}{l}\text { Total Shopping } \\
\text { Total Donation }\end{array}$} & 463588235169.408 & 75 & & & \\
\hline & & 1236662198.355 & 75 & & & \\
\hline \multicolumn{7}{|c|}{ a. R Squared $=.012($ Adjusted R Squared $=-.001)$} \\
\hline & 51 (Adjusted $\mathrm{F}$ & $\mathrm{red}=.038)$ & & & & \\
\hline
\end{tabular}

In this research, the concern of some people about the NNCM program launched by Bank Indonesia in Islamic boarding schools would encourage more consumptive students was not proven. Even though in theory, differences in expenditure instruments (cash and debit cards) are suspected to encourage users to behave differently. In the experiments conducted using direct participants from the boarding school environment, it did not support the argument of mental accounting theory. The results of this study did not support Leon (2012) and Runnemark et al. (2015) that shopping with a debit card will lead to more consumptive behaviour than cash. Perhaps better religious knowledge among students will reduce the tendency to behave consumptively. The survey results conducted by Ardyanti and Kardoyo (2018) on university students support the assumption. Religiosity is one factor that can put the brakes on consumptive behaviour. Another factor might be the policy of the management of the Islamic Boarding School that students are not allowed to get excess pocket money from their parents.

Different from the results of the second test which supported the argument that the way of shopping practices encouraged different donation behaviour. The students who shopped using a debit card tended to choose to donate than those who shopped using 


\section{Kresnawati, Wahib, \& Pertiwi \\ Mental Accounting Experiment: Mode of Payment Effect on Treating Money}

cash. This means that payment methods using a debit card can lead to different behavior in treating money, especially for charity activity.

Islamic boarding school is a unique social environment. In this environment, it mingled various strata of the social level of students' parents. However, a strict management policy by the management of the Islamic boarding school makes students can release those differences and mingle as a big family. Obedience to teachers (ustadz and ustadzah) as a substitute for parents makes students easier to be directed compared to when they study in general schools. A limited and relatively separate environment from other communities also educates students to be more independent and not too influenced by promiscuity. These things contributed to the success of the launching of NNCM in the boarding school environment by Bank Indonesia.

In Addition to the attitude of no extravagance in spending, the use of debit cards also has a better impact on students, in which it makes them easier to donate. This will provide good benefits for boarding schools and the surrounding environment if managed properly. The students do not feel lost a lot of money or feel ashamed when they only donate as much as the price of candy. Instead, they feel happy because they can donate even though in terms of it's nominal it is immaterial for them.

The results of the perception questionnaire distributed to them also supported that shopping using a debit card provided many conveniences, including more flexibility (89.5\%), no need to busily carrying cash $(86.8 \%)$ and safer from loss $(73.7 \%)$. Thus, in general, the results of this study had a positive impact on the NNCM program launched by Bank Indonesia in the Islamic boarding school environment.

\section{Conclusion}

This study aims to examine whether differences in the way of shopping, using a debit card and cash affect the size of the amount of shopping and donations. The test results show that the payment method does not affect the nominal amount of spending made by the students, but it affects the amount of donations. Consumers who make payments by debit cards show a greater amount of donations than those using cash.

Theoretically, the results of this study contribute to the development of mental accounting theory, which is in the context of the participant and the background of the participant is very important to consider when testing this theory. This can be seen from the hypothesis 1 which is not supported. In practice, the results of this study can be an academic study for Bank Indonesia which launched NNCM in Islamic boarding schools. Unsupported hypothesis 1 provides an opportunity for Bank Indonesia to continue the program without worrying that students would be more consumptive when the payment patterns were changed from cash to debit cards. The questionnaire results also 


\author{
Kresnawati, Wahib, \& Pertiwi \\ Mental Accounting Experiment: Mode of Payment Effect on Treating Money
}

showed that students were not resistant to the program and supported it because they gain benefits from it.

The weakness of this study is that students who become participants have limited time to go out of the boarding school, so there is an impression of being hasty in conducting the experiments. This can be seen from the number of participants who did not pass the manipulation test. To encourage representation, the researcher used the betweensubject design. One weakness of this method is that it cannot eliminate the character difference inherent in each participant. Future studies can consider using within-subject designs that will reflect more the moving process of the use of shopping from cash to debit cards. Another limitation is that this study only uses female students. Further research can compare whether gender will also affect consumer behaviour and donations in the boarding school environment such as the result of the study by Mesch et al. (2011) and Nandanan and Fernandez (2017).

\title{
References
}

Antonio, M. S., Yulizar, D. S., \& Muhammad, T. (2012). An Analysis of Islamic Banking Performance: Maqashid Index Implementation in Indonesia and Jordania. Journal of Islamic Finance, 1(1), 012 - 029.

Ardyanti, N., \& Kardoyo. (2018). Determinants of Consumption Behavior Among Students. Dinamika Pendidikan, 13(1), 30-41. https://doi.org/10.15294/dp.v13i1.15112

Bank Indonesia. (2006). Upaya Meningkatkan Penggunaan Alat Pembayaran Non Tunai Melalui Pengembangan E-Money. Retrieved from https://www.bi.go.id/id/publikasi/sistempembayaran/riset/Pages/Kajian e money.aspx

Bank Indonesia. (2019). Jumlah APMK Beredar. Retrieved from https://www.bi.go.id/id/statistik/sistem-pembayaran/apmk/contents/jumlah apmk beredar.aspx

BAZNAS. (2019). BAZNAS Sampaikan 6 Capaian Sukses Pada Rakornas Zakat 2019. Retrieved August 29, 2019, from https://baznas.go.id/beritadetail/getBeritaDetail/BAZNAS Sampaikan_6_Capaian Sukses Pada Rakornas Zakat_2019/187

Ding, Z., \& Ng, F. (2007). Construction Management and Economics Reliability and validity of the Chinese Version of McAllister's trust scale Reliability and Validity of the Chinese version of McAllister's Trust Scale. Construction Management and Economics, 25, 1107-1117. https://doi.org/10.1080/01446190701670357

Douglas, S. P., \& Craig, C. S. (2007). Collaborative and Iterative Translation: An Alternative Approach to Back Translation. Journal of International Marketing, 15(1), 30-43. https://doi.org/10.1509/jimk.15.1.030

Galperti, S. (2019). A Theory of Personal Budgeting. Theoretical Economics, 14, 173-210.

Helion, C., \& Gilovich, T. (2014). Gift Cards and Mental Accounting: Green-lighting Hedonic Spending. Journal of Behavioral Decision Making, 27, 386-393.

https://doi.org/10.1002/bdm.1813 


\section{Kresnawati, Wahib, \& Pertiwi \\ Mental Accounting Experiment: Mode of Payment Effect on Treating Money}

Hirschman, E. C. (1979). Differences in Consumer Purchase Behavior by Credit Card Payment System. Joumal of Consumer Research, 6(1), 58-66. https://doi.org/10.1086/208748

Leon, M. M. (2012). Money Illusions: A Study on Payment Mode and Economic Framing. California State University, Fullerton.

Mesch, D. J., Brown, M. S., Moore, Z. I., \& Hayat, A. D. (2011). Gender Differences in Charitable Giving. International Journal of Nonprofit and Voluntary Sector Marketing, 16(4), 342-355. https://doi.org/10.1002/nvsm

Monger, J. E., \& Feinberg, R. A. (1997). Mode of Payment and Formation of Reference Prices Mode of Payment and Formation of Reference. Pricing Strategy and Practice, 5(4), 142-147. https://doi.org/10.1108/09684909710184635

Morewedge, C. K., Gilbert, D. T., Berkovits, M. J., \& Wilson, T. D. (2007). Mispredicting the Hedonic Benefits of Segregated Gains. Journal of Experimental Psychology: General, 136(4), 700-709. https://doi.org/10.1037/0096-3445.136.4.700

Muamar, A., \& Alparisi, A. S. (2017). Electronic Money (E-Money) in Maqashid Al-Sharia Perspective. Journal of Islamic Economics Lariba, 3(2), 75-84. Received from: https://journal.uii.ac.id/JIELariba/article/view/9657

Nahartyo, E. (2012). Desain dan Implementasi Riset Eksperimen. Yogyakarta: Penerbit UPP STIM YKPN.

Nandanan, P., \& Fernandez, S. P. (2017). A Study on the Gender Differences in the Spending Attitude and Behavior of IT Professionals in Urban Bangalore. International Journal of Business and Management Invention, 6(7), 55-59. Received from: https://www.ijbmi.org/papers/Vol(6)7/Version-3/H0607035559.pdf

Prelec, D., \& Loewenstein, G. (1998). The Red and the Black: Mental Accounting of Savings and Debt. Marketing Science, 17(1), 4-28. https://doi.org/10.1287/mksc.17.1.4

Prelec, D., \& Simester, D. (2001). Always Leave Home Without It: A Further Investigation of The Credit-Card Effect on Willingness to Pay. Marketing Letters, 12(1), 5-12. https://doi.org/10.1023/a:1008196717017

Raghubir, P., \& Srivastava, J. (2008). Monopoly Money: The Effect of Payment Coupling and Form on Spending Behavior. Journal of Experimental Psychology: Applied, 14(3), 213225. https://doi.org/10.1037/1076-898X.14.3.213

Republika Online. (2015). Santri Sunan Pandanaran Kini Wajib Transaksi tanpa Uang Tunai. Republika Online.

Rosiana, R. (2018). Pemikiran Imam Al-Ghazali Tentang Uang. Jurnal Ilmiah Ekonomi Islam, 4(01), 14-27. https://doi.org/10.29040/jiei.v4i1.161

Runnemark, E., Hedman, J., \& Xiao, X. (2015). Do consumers pay more using debit cards than cash? Electronic Commerce Research and Applications, 14(5), 285-291. https://doi.org/10.1016/j.elerap.2015.03.002

Shefrin, H., \& Thaler, R. H. (1992). Mental Accounting, Saving, and Self-Control. In G. Loewenstein \& J. Elster (Eds.), Choice Over Time (pp. 287-330). New York, NY, US: Russell Sage Foundation.

Soetevent, A. R. (2011). Payment Choice, Image Motivation and Contributions to Charity: Evidence from a Field Experiment. American Economic Journal: Economic Policy, 3(February), 180-205. https://doi.org/10.1257/pol.3.1.180 


\section{Kresnawati, Wahib, \& Pertiwi \\ Mental Accounting Experiment: Mode of Payment Effect on Treating Money}

Soman, D. (2001). The Mental Accounting of Sunk Time Costs: Why Time is not Like Money. Journal of Behavioral Decision Making 14, 169-185.

https://doi.org/10.1002/bdm.370

Soman, D. (2003). The Effect of Payment Transparency on Consumption: QuasiExperiments from the Field. Marketing Letters, 14(3), 173-183.

https://doi.org/10.1023/a:1027444717586

Thaler, R. H. (1980). Toward a Positive Theory of Consumer Choice. Journal of Economic Behavior and Organization, 1, 39-60. https://doi.org/10.1016/0167-2681(80)90051-7

Thaler, R. H. (1985). Mental Acconting and Costumer Choice. Marketing Science, 4, 199-214.

Thaler, R. H. (1999). Mental Accounting Matters. Journal of Behavioral Decision Making, 12, 183-206. https://doi.org/10.1002/(sici)1099-0771(199909)12:3\%3C183::aidbdm318\%3E3.0.co;2-f

Thomas, M., Desai, K. K., \& Seenivasan, S. (2011). How Credit Card Payments Increase Unhealthy Food Purchases: Visceral Regulation of Vices. Journal of Consumer Research, 38(1), 126-139. https://doi.org/10.1086/657331 